DOI: 10.15679/bjwr.v4i2.53

\title{
A REVIEW OF THE INVASIVE EURASIAN COLLARED DOVE AND POSSIBLE RESEARCH METHODS IN THE FUTURE
}

\author{
Bagi Z. ${ }^{1}$, Kraus H. R. ${ }^{2,3}$, Kusza S. ${ }^{1}$,
}

Summary: The Eurasian Collared Dove Streptopelia decaocto is one of the most successfuly expanding vertebrate species in the world; therefore, it has attracted special scientific focus. This review summarises the species' achievements related to its rapid expansion and the ecological consequences with regard to the population genetic assessments. It also highlights the expansion dynamics of the species and the ecosystems to which it is most adapted. Finally, the effects of this species on the newly colonised ecosystems are illustrated. The study of the genetic structure between populations to make inferences about expansion dynamics has been neglected so far. Thus, we survey the opportunities of using molecular markers for genetic analysis in populations of Eurasian Collared Dove as a possible means for future studies. This work is important given the lack of information on the mentioned fields, and it calls attention to the importance of further interdisciplinary studies from different scientific fields using this species.

Keywords: colonisation; mitochondrial DNA; microsatellites; ecology; diversity; Streptopelia decaocto

\section{Introduction}

The Eurasian Collared Dove Streptopelia decaocto (Frivaldszky, 1838) has shown a rapid expansion worldwide (Fisher, 1953; Gorski, 1993; Kasparek, 1996; Romagosa \& Labisky, 2000). During the conquest of new territories, endogenous communities can be in conflict with newcomers (Bled et al., 2011). The Collared Dove originated from India, and it has colonised the Middle East and Europe throughout the last few centuries (Stresemann \& Nowak, 1958; Smith, 1987; Gorski, 1993; Romagosa \& McEneaney, 1999). The colonisation of Europe occurred almost entirely within the last 100 years (Nowak, 1965; Snow \& Perrins, 1998; Crooks et al., 1999; Rocha-Camerero \& Hidalgo de Trucios 2002; Eraud et al., 2007), and it reached North Africa in the late 1980s, where its spread is still continuing (Hengeveld, 1993; Moali et al., 2003; Thévenot et al., 2003). Although the expansion into Europe could be considered complete, it is still spreading in North America as an invasive species (Romagosa \& McEneaney, 1999; Romagosa \& Labisky, 2000; Hooten \& Wikle, 2008; Fujisaki et al., 2010; Bled et al., 2011). In Europe, the breeding population is estimated to the of number 7,910,000 - 14,300,000 breeding pairs, equating to 24,100,000 - 43,000,000 individuals. Europe represents ca. $40 \%$ of the global range; therefore, a revised estimate of the global population size is $60,000,000-110,000,000$ individuals. The distribution area is $93,400,000 \mathrm{~km}^{2}$ (BirdLife International, 2017).

Invasive species are considered the second major cause of global biodiversity loss, directly behind habitat destruction (Wilcove et al., 1998). Therefore, the importance of research into such

\footnotetext{
${ }^{1}$ Bagi Zoltán, PhD candidate; Szilvia Kusza. PhD, University of Debrecen, Institute of Animal Science, Biotechnology and Nature, Debrecen, Hungary

${ }^{2}$ Robert H Kraus, PhD, Max Planck Institute for Ornithology, Department of Migration and Immuno-Ecology, Am Obstberg 1, D78315 Radolfzell, Germany; ${ }^{3}$ University of Konstanz, Department of Biology, D-78457 Konstanz, Germany
} 
species is rapidly increasing. A growing number of studies have highlighted the important contribution of genetics in this field (Lee, 2002; Frankham, 2005; Prentis et al., 2008). Rapid adaptive responses to anthropogenic changes have been known for decades (Sax et al., 2007). Several works have shown that comparably quick and dramaticevolutionary responses are common also under natural conditions in the absence of anthropogenic selective pressures, that is, in response to natural selective pressures (Stockwell et al., 2003; Cox, 2004). The majority of these data come from documented evolutionary changes in exotic species or in native populations responding to exotic species (Cox, 2004; Carroll et al., 2005; Huey et al., 2005). Stockwell et al. (2003) argue that our emerging understanding of the speed of evolution should change the questions being asked by conservation biologists; for example, do deliberate attempts to maintain genetic diversity within managed populations impede selective genetic adaptation? In addition, large and rapid evolutionary genetic changes suggest that greater efforts should be made to combine ecological and evolutionary perspectives in both theoretical and empirical studies (Sax et al., 2007). The Collared Dove is an invasive species in large parts of its distribution, but only few genetic studies have been attempted so far (Johnson \& Clayton, 2000a; Johnson \& Clayton, 2000b; Johnson et al., 2001; Kerr et al., 2007; Johnsen, 2010; Schindel et al., 2011; Aliabadian et al., 2013; Awan et al., 2013), but none of them has specifically focused on the genetic diversity of the species. Exploring genetic diversity of Collared Dove populations will expand our knowledge of the potential for adaptation of the species and help estimate the chances of long term survival of populations. Furthermore, it is an ideal model system for studying rapid evolutionary changes after a quick expansion. It is important to reconstruct the routes of invasion and to generate and test hypotheses concerning the environmental and evolutionary factors responsible for biological invasions in general (Estoup \& Guillemaud, 2010).

The recent history of a massive colonisation of Europe by Collared Dove and its invasion of North America following the escape of captive individuals has become one of the prime examples of both colonisation and invasion biology. However, considering its importance, there are relatively few genetic studies of this species. Genetic studies into range dynamics have been termed "key features in determining whether invasive species establish and spread” (Sakai et al., 2001). Understanding the population genetic processes at the edge of an expansion (compared with interior populations) can be extremely valuable for understanding the causes and consequences of range shifts at the same time (Excoffier \& Ray, 2008). It is therefore time to review studies of the population dynamics and ecology of Collared Dove in the overall context of genetic diversity studies of similar cases because it is paramount to understanding the recent, spectacular spread of the Collared Dove. Authors aim is to summarize the results of the Collared Dove's expansion. Furthermore, the aim is to draw attention to a possible new direction of studying this species, which can be a study of the genetic diversity of the Collared Dove. This may give the newest and the most useful information about the species and its successful expansion. In the second part of this paper, we will review the genetic analysis methods that were useful in examining similar species or similar expansions.

\section{Ecological Studies}

Ecological studies are obviously required for understanding the impacts of the successful invader Collared Dove in new ecosystems. Ecological studies of colonisation and invasion processes may also provide a framework for understanding evolution more generally because established populations of many introduced species are isolated from source populations and may diverge rapidly from their ancestors through a combination of divergent natural selection and genetic drift (Duncan et al., 2003); therefore, they may demonstrate genetic and life-history differentiation (Baker, 1922; Selander \& Johnston, 1967; Baker \& Moeed, 1987). The European range of the species was limited to Turkey and the Balkan region in the early 1930s (Hudson, 1965). From there, the European expansion started, which ended in the past decade when the species reached even remote locations and hit the limits of its potential climatic niche (Fujisaki et al., 2010). The 
dispersal pattern progressed in a generally northwest direction and has been shown to include small foci lying ahead of larger colonised regions. Over time, these foci filled the void areas as the local populations grew (jump dispersal: Hudson, 1972; Romagosa \& Labisky, 2000). Another mechanism of dispersal is the low density in urban areas during the breeding season compared with winter, when larger flocks congregate in cities. The breeding population disperses in the marginal zone of the town and also outside the city area. This eliminates competition between males for territories and nesting sites and enables successful reproduction. Robertson (1990) studied the nesting characteristics and breeding success and then compared them with the results of studies in Asia and Central Europe. The results showed that the breeding season starts and finishes approximately one month later in rural Britain than at similar degrees of latitude in Eastern Europe although the populations having been isolated for less than 50 years; however, the cause could not be discerned. There are similarities in habitat preference and dispersal patterns in the U.S.A. compared with Europe. In northern Colorado, Collared Doves inhabit rural farming landscapes similar to the breeding habitat in Europe (Beckett et al., 2007). The incidence and abundance of this species are also associated with human-modified landscapes within Florida (Bonter et al., 2010). High human commensalism is a unique attribute of this species. In Britain, its distribution is associated with human settlements such as suburban gardens and town parks with a mix of shrub and tree cover, including human-made structures (Hengeveld, 1988).

Eraud et al. (2007) studied the spatial and temporal dispersal dynamics of the Collared Dove in France. Their results accent the importance of estimating detection probabilities to draw proper inferences about the spatial and temporal dynamics of the colonisation pattern of Streptopelia decaocto. In contrast with previous knowledge about the spatial dynamics from national atlas surveys, they provided evidence that the range of this species is still increasing in France. Their results, such as the regional specificity in colonisation probabilities and time variation in local extinctions, were in accordance with the expectations from invasion and metapopulation theory. Eraud et al. (2011) demonstrated in another study that the survival rate of juvenile doves is higher in rural areas. This result suggests that the range expansion of the Collared Doves should be faster in regions where urban areas are smaller but more closely spaced.

Due to human mediation, the Collared Dove also recently spread in Central and North America, where Florida constituted the starting point (Garrido \& Kirkconnell, 1990; Barré et al ., 1996; Almazán-Núñez, 2014). Romagosa \& Labisky (2000) studied the dispersal of the Collared Dove in Florida from the mid1980s to the 1990s, comparing the patterns of invasion of the species between Florida and Europe. They found that the number of birdwatching sites where the Collared Dove was recorded in Florida increased from 4\% to 82\% between 1986 and 1996 and correctly forecasted that this rapid expansion will not stop at the border of Florida and that the species will quickly spread in North America. This has already occurred, and the Collared Dove has reached Canada (Syroteuk, 2008). Mayr (1950) assumed that the expansion in Europe was initiated by a genetic alteration of peripheral populations. However, no genetic studies have been conducted to verify this hypothesis. The range expansion in Florida was most prevalent along the coast (Romagosa \& Labisky, 2000) in accordance with observations in Britain where the bird is most abundant around the coastal belt (Hudson, 1972). Romagosa \& Labisky (2000) also reported a possible dispersal pattern along rivers in Florida. Fujisaki et al. (2010) examined how the presence and abundance of Collared Dove were related to environmental and human-influenced landscape features to provide a better understanding of the range expansion trajectory and the potential for future expansion and population growth. The results showed that the distance from the first route was an important explanatory variable for the species' presence but not for abundance; the greater the distance from the first route, the more likely it was that the species was absent. The average annual minimum temperature was a strong explanatory variable of species occurrence, too. Collared Doves tended to be absent in areas with low minimum temperature. The species was observed in only $3 \%$ of locations where the average annual minimum temperature was below $0^{\circ} \mathrm{C}$ over the past ten years. The precipitation did not affect occurrence. Based on our literature survey, it occurred to 
us that temperature was the most important factor in the spread because the species has been in Turkey since the 16th century whereas the European expansion began only in the late 19th century (Hofstetter, 1954; Smith, 1987; Gorski, 1993; Romagosa \& McEneaney, 1999). This period coincides with the end of the Little Ice Age in Europe, traditionally defined as the period between 1550 and 1850 AD (Jones \& Bradley, 1992). This was a period characterised by a mean annual air temperature of ca. $1{ }^{\circ} \mathrm{C}$ lower than today (Hughes, 2010). Presumably, this cold period halted the expansion. After the Little Ice Age, agriculture thrived due to recurrent warming. This warming may have been responsible for range expansion directly through the effects of elevated minimum temperatures that fit the niche of Collared Dove, and also indirectly by increasing the availability of agricultural habitats. The results of Scheidt and Hurlbert (2015) confirmed that land cover and climate both have important effects on the population growth rates and carrying capacities of Collared Dove populations.

In summary, in various studies several factors have been identified or at least proposed as a cause of the fast colonisation dynamics of the Collared Dove, some of which are closely related to human activities (Mayr, 1963; Coombs et al., 1981; Cramp, 1985; Temple, 1992; Gibbons et al., 1993; Gorski, 1993; Stevenson \& Anderson, 1994). These are genetic changes of colonisation behaviour, emigration unrelated to population density, high adaptability to human inhabitation, generalist diet, and high reproductive output with multiple and relatively large broods: 4-5 broods per year compared to Columba palumbus with 2-3 broods per year (Glutz \& Bauer, 1980) - (Romagosa \& Labisky, 2000). The expansion of the Collared Dove is a very complex phenomenon, and a large number of ecological determinants have still not been addressed, for example, the impact of predators and hunting on population size and structure. Little is known about the changes in abundance of this species, which can occur in urban habitats during the winter (Bozsko \& Juhász, 1984).

\section{Molecular Genetic Studies and the Applicable Methods}

Mayr (1950) assumed that invasions may be caused by genetic changes in the peripheral part of a species' geographical range. Hengeveld (1993) recommended a study about the genetics of peripheral populations of the Collared Dove, especially of the genetic differentiation between colonised Europe and other (e.g., Asian) parts of the Collared Dove's range. It would also be interesting to see if such differentiation could take place in the vast and ecologically varied subcontinent of North America. Thus far, no survey of Collared Dove molecular genetic diversity has been attempted. However, now, relatively soon after the expansion phase, such studies would be greatly beneficial for research on Collared Dove and for the study of colonisation and range expansion more generally. Therefore, this area should receive more attention in the coming years. Most genetic studies of this species have concerned DNA barcoding (Kerr et al., 2007; Johnsen et al., 2010; Schindel et al., 2011; Aliabadian et al., 2013; Awan et al., 2013). DNA barcoding is a taxonomic method that uses a short genetic marker in an organism's DNA to identify it as belonging to a particular species (Ratnasingham \& Hebert, 2007). This method is based on the premise that a short, standardised sequence can distinguish between individuals of a species because the genetic variation between species exceeds that within species (Hebert et al., 2003). The mitochondrial cytochrome c oxidase I (COI) gene was selected as the standard locus for DNA barcoding. Although this has been primarily introduced as a taxonomic tool, it can be used for population genetic analysis, too. According to Hajibabaei et al. (2007), it can provide an early insight into the patterning of genetic diversity between species because barcoding typically targets a large number of species. It can be a powerful tool for facilitating comparative studies of genetic diversity in different species or examining the genetic diversity within species. Moreover, they note that the accumulation of large amounts of barcode sequences and supplemental meta-data such as ecological and geographical information allows for the measurement of haplotype diversity, habitat continuity and genetic structure in species within a taxonomic assemblage or geographical region. Therefore, 
DNA barcoding projects help in enriching GenBank (Benson et al., 2015) with more Collared Dove COI sequences. COI became a successful system used to identify most bird species (Baker et al., 2009). However, the benefits of COI, i.e., its conservation across species making it possible to use the same marker across a great number of divergent species, can limit its applicability within species. Other genes in the mitochondrial genome are therefore often used to study population processes (Kocher et al., 1989; Moritz, 1994).

Phylogenetics explores the divergence among taxa (Gibb \& Penny, 2010), and mitochondrial DNA (mtDNA) sequences have been successfully used to estimate phylogenetic relationships among basically all bird taxa and to study population genetics and molecular evolution (Kan et al., 2010). Practically every molecular study involves mtDNA haplotyping at some stage (Galtier et al., 2009). Mitochondrial DNA has also been used to explore phylogenetic relationships in Columbidae (Johnson \& Clayton, 2000a; Johnson \& Clayton, 2000b; Johnson at al., 2001; Shapiro et al., 2002,). The following markers were used in the taxonomic examination of the genus Streptopelia. Johnson et al. (2001) used both nuclear and mitochondrial genes: cytochrome b (cytb), cytochrome oxidase I (COI), NADH dehydrogenase subunit 2 (ND2) and the nuclear gene $\beta$-fibrinogen intron 7 (FIB7). Despite the lower homoplasy present in the FIB7 sequences, the mitochondrial genes provided better resolution for the phylogeny of Streptopelia.

Regarding intraspecific mtDNA studies, the Great Tit (Parus major) is a good species for comparison because it displays population expansion in an anthropogenic environment similar to the Collared Dove. Kvist et al. (2007) studied Eurasian populations of P. major by mitochondrial control region sequences and microsatellites. The Great Tit has experienced demographic and spatial expansions during the last century at several sites at the edges of its distribution range. Kvist et al. (2007) found that expansions have resulted in dissimilar patterns of molecular diversity between range edges and core distribution. Grosso et al. (2006) used the cytochrome $b$ region of the Wood Pigeon Columba palumbus to examine geographic divergence. C. palumbus has a wide distribution from the Mediterranean region to western Asia. In this case, data from the cytochrome $b$ sequence did not support the existence of a geographically based divergence among $C$. palumbus populations, which may indicate the persistence of gene flow. Ball \& Avise (1992) examined phylogeographic population structures by mtDNA markers within six avian species with continentwide distributions in North America. The magnitude and geographic pattern of mtDNA variation differed considerably among species. The Mourning Dove (Zenaida macroura), which uses similar habitat as the Collared Dove, exhibited fairly low levels of mtDNA polymorphism and a shallow phylogeographic structure. Another example of mtDNA analysis of the distribution and genetic structure in a pigeon species is the Japanese Wood Pigeon (Columba janthina), where levels of gene flow between populations were measured and conservation priorities were derived (Seki et al., 2007).

Although the population of Collared Dove is increasing globally, there is an ongoing decrease in many countries at the same time (BirdLife International, 2015). Therefore, some isolated populations may occur. In such cases, mtDNA is useful, as outlined by Brown et al. (2004), who examined the genetic variation of avian populations in isolated forest fragments. They used mtDNA sequence analysis from which they could infer aspects of the population structure of four species of underbrush birds from four sites in the southern Costa Rican rainforest. The authors demonstrated that deforestation in recent decades has led to the fragmentation of habitat, causing a serious decrease in nucleotide diversity within populations. That study found high levels of population differentiation over a relatively small geographic scale in three of the four studied species. The reduced nucleotide diversity in the isolated populations indicated that the effects of strong genetic drift are being manifested within isolated habitat fragments. These examples indicate that mtDNA sequencing will be useful for the examination of small, isolated populations of Collard Dove, too.

For the Collared Dove, relatively few generations have passed since the colonisation, and we therefore expect a generally low degree of genetic differentiation. Furthermore, Columbiformes are 
strong fliers able to move long distances (Goodwin, 1977; Baptista et al., 1997). Therefore, except under special circumstances (insurmountable ecological barriers) high gene flow is expected among populations with no morphological differentiation (Santiago-Alarcon et al., 2006). According to Santiago-Alarcon et al. (2006) rapid population expansion could explain reduced within-population diversity (versus global diversity linked to founder events: Hedrick, 2000; McCoy et al., 2003). In such cases, microsatellite markers are usually more suitable than mitochondrial DNA because they have a higher temporal resolution. For example, Santiago-Alarcon et al. (2006) studied the genetic population structure and morphological differentiation among island populations of the Galapagos Dove (Zenaida galapagoensis). In this study, five microsatellite markers were used to determine genetic diversity, population structure, gene flow, and effective population size. They found that populations with greater geographical separation were not more genetically distinct than those closer to one another and estimated that gene flow would be high. There were no significant differences in allelic richness and gene diversity among populations. Tanksley (2000) used microsatellite markers and reported no genetic structure in White-winged Doves (Streptopelia reichenowi) sampled in North America. However, an mtDNA study revealed slight differentiation between populations according to a historical east-west division of its distribution (Pecos River in Texas) that is currently disappearing due to the species' range expansion (Pruett et al., 2000). Lopes et al. (2007) used both microsatellite loci and mitochondrial DNA analysis in wading birds in Brazilian Pantanal. They determined the genetic variability within and between populations, which is important information for assessing a population's chance of survival, by microsatellites while the demographic history of populations was revealed using mtDNA. Monceau et al. (2013) investigated both past and recent island differentiation and micro-evolutionary changes in the Zenaida Dove (Zenaida aurita) based on combined information from one mitochondrial (COI) and 13 microsatellite markers and four morphological characters. This Caribbean endemic and abundant species has a large distribution, and two subspecies are supposed to occur (Z. a. zenaida and Z. $a$. aurita). The level of divergence between those two lineages was too moderate to fully corroborate the existence of two subspecies. Colonisation of the studied islands appeared to be a recent process. However, both phenotypic and microsatellite data suggest that differentiation is already under way between all of them, partly associated with the existence of limited gene flow. Differentiation for morphological traits was more pronounced than for neutral markers. These results suggest that despite recent colonisation, genetic drift and/or restricted gene flow are promoting differentiation for neutral markers. The above examples are intended to demonstrate the benefits of genetic study of an expansionary species. This method reveals relationships without which we can not understand the behaviour of the species in the context of expansion. In such cases, the most common used marker is the mtDNA and the microsatellites. MtDNA is haploid and maternally inherited; thus, it is suitable primarily for the analysis of the phylogenetic and phylogeographic history. However, microsatellite markers are more sensitive than mtDNA because microsatellites display higher polymorphism (Nugroho, 2002). The two kinds of markers complement each other in this type of analysis, and such combined knowledge is essential for effective conservation management.

\section{Conclusion}

To our knowledge, there has not yet been a single study to measure the genetic diversity of the Collared Dove either with mtDNA or nuclear DNA such as microsallites. As a first step, the focus should lie on gathering mtDNA data from the Collared Dove to deduce preliminary models of their population structure and history on the species level. However, the application of microsatellite markers will be the logical next step for the examination of the genetic structure within populations. Other types of powerful nuclear marker sets such as single nucleotide polymorphisms (SNPs; for a discussion on genetic markers in ornithology see: Wink, 2006) have already enabled the study of curious recent changes in bird species ranges and migration patterns, for example in the Barnacle Goose (Jonker et al., 2013). However, when genetic structure is very weak or absent, even high 
power genetic markers may fail to reveal genetic structure (Kraus et al., 2013). Further advances in genomic technology are currently transforming avian genetics and are likely to be the ultimate tool in understanding the actual genetic basis (if there is one) of the Collared Dove's colonisation and invasion potential (Kraus \& Wink, 2015).

\section{Acknowledgments \\ The manuscript has been proof-read by Wiley Editing Services.}

\section{References}

1. Aliabadian, M., Beentjes, K. K., Roselaar, C. S., van Brandwijk, H., Nijman, V., Vonk, R. (2013) DNA barcoding of Dutch birds, 25-48. In: Nagy, Z. T., Backeljau, T., De Meyer, M., Jordaens, K. (Eds.), DNA barcoding: a practical tool for fundamental and applied biodiversity research, ZooKeys, 365, pp. 25-48. doi: 10.3897/zookeys.365.6287.

2. Almazán-Núñez, R. C. (2014) Nuevos registros de la paloma turca (Streptopelia decaocto) en el estado de Guerrero, México, Acta zoológica mexicana, 30(3), pp. 701-706.

3. Awan, A. R., Umar, E., ul Haq, M. Z., Firyal, S. (2013) Molecular classification of Pakistani collared dove through DNA barcoding, Molecular biology reports, 40(11), pp. 6329-6331.

4. Baker, A. J. (1992) Genetic and morphometric divergence in ancestral European and descendent New Zealand populations of chaffinches (Fringilla coelebs), Evolution, 46(6), pp. 1784-1800.

5. Baker, A. J., Moeed, A. (1987) Rapid genetic differentiation and founder effect in colonizing populations of common mynas (Acridotheres tristis), Evolution, 41(3), pp. 525-538.

6. Baker, A. J., Tavares, E. S., Elbourne, R. F. (2009) Countering criticisms of single mitochondrial DNA gene barcoding in birds, Molecular Ecology Resources, 9(s1), pp. 257-268.

7. Ball, Jr. R. M., Avise, J. C. (1992) Mitochondrial DNA phylogeographic differentiation among avian populations and the evolutionary significance of subspecies, The Auk, pp. 626-636.

8. Baptista, L. E., Trail, P. W., Horblit, H. M. (1997) Family Columbidae (pigeons and doves), pp. 60-243. In: del Hoyo, J., Elliot, A., Sargatal, J. (Eds.), Handbook of the birds of the world, vol. 4. Sandgrouse to Cuckoos, Lynx Edicions, Barcelona, Spain.

9. Barré, N., Feldmann, P., Tayalay, G., Roc, P., Anselme, M., Smith, P. W. (1996) Status of the Eurasian Collared-Dove (Streptopelia decaocto) in the French Antilles, El Pitirre, 9(4), pp. 2-4.

10. Beckett, S. M., Komar, N., Doherty, Jr. P. F. (2007) Population estimates for Eurasian collared-dove in northeastern Colorado, The Wilson Journal of Ornithology, 119(3), pp. 471-475.

11. Benson, D. A., Clark, K., Karsch-Mizrachi, I., Lipman, D. J., Ostell, J., Sayers, E. W. (2015) 655 Genbank, Nucleic Acids Res, 43, pp. D30-35.

12. BirdLife International. (2015) European Red List of Birds. Luxembourg: Office for Official Publications of the European Communities.

13. BirdLife International. (2017) Species factsheet: Streptopelia decaocto. Downloaded from http://datazone.birdlife.org/species/factsheet/eurasian-collared-dove-streptopelia-decaocto/text on 04/24/2017 (accessed 24.07.2017).

14. Bled, F., Royle, J. A., Cam, E. (2011) Hierarchical modeling of an invasive spread: the Eurasian Collared-Dove Streptopelia decaocto in the United States, Ecological Applications, 21(1), pp. 290-302.

15. Bonter, D. N., Zuckerberg B., Dickinson, J. L. (2010) Invasive birds in a novel landscape: habitat associations and effects on established species, Ecography, 33(3), pp. 494-502.

16. Bozsko, Sz., Juhász, L. (1984) Comparative survey of the Collared Dove (Streptopelia decaocto Friv.) population at five county seats (Nyíregyháza, Debrecen, Eger, Győr, Zalaegerszeg) in Hungary, Aquila, 91, pp. 115-149.

17. Brown, L. M., Ramey, R. R., Tamburini, B., Gavin, T. A. (2004) Population structure and mitochondrial DNA variation in sedentary Neotropical birds isolated by forest fragmentation, Conservation Genetics, 5(6), pp. 743-757.

18. Carroll, S. P., Loye, J. E., Dingle, H., Mathieson, M., Famula, T. R., Zalucki, M. P. (2005) And the beak shall inherit evolution in response to invasion, Ecology Letters, 8(9), pp. 944-951.

19. Coombs, C. F. B., Isaacson, A. J., Murton, R. K., Thearle, R. J. P., Westwood, N. J. (1981) Collared doves (Streptopelia decaocto) in urban habitats, Journal of Applied Ecology, pp. 41-62.

20. Cox, G. W. (2004) Alien Species and Evolution: The Evolutionary Ecology of Exotic Plants, Animals, Microbes, and Interacting Native Species. Island Press.

21. Cramp, S. (1985) Handbook of the birds of Europe, the Middle East and North Africa, Vol. 4, terns to woodpeckers, Oxford University Press, New York, New York.

22. Crooks, J. A., Soulé, M. E., Sandlund, O. T. (1999) Lag times in population explosions of invasive species: causes and implications, Invasive species and biodiversity management, pp. 103-125.

23. Duncan, R. P., Blackburn, T. M., Sol, D. (2003) The ecology of bird introduction,. Annual Review of Ecology, Evolution, and Systematics, 34(1), pp. 71-98.

24. Eraud, C., Boutin, J., Roux, D., Faivre, B. (2007) Spatial dynamics of an invasive bird species assessed using robust design occupancy analysis: the case of the Eurasian Collared Dove (Streptopelia decaocto) in France, Journal of Biogeography, 34(6), pp. 1077-1086. 
25. Eraud, C., Jacquet, A., Legagneux, P. (2011) Post-fledging movements, home range, and survival of juvenile Eurasian collared-doves in western France, The Condor, 113(1), pp. 150-158.

26. Estoup, A., Guillemaud, T. (2010) Reconstructing routes of invasion using genetic data: why, how and so what?, Molecular ecology, 19(19), pp. 4113-4130.

27. Excoffier, L., Ray, N. (2008) Surfing during population expansions promotes genetic revolutions and structuration, Trends in ecology \& evolution, 23(7), pp. 347-351.

28. Fisher, J. (1953) The Collared Turtle Dove in Europe, British Birds, 46, pp. 153-181.

29. Frankham, R. (2005) Resolving the genetic paradox in invasive species, Heredity, 94(4), pp. 385-385.

30. Fujisaki, I., Pearlstine, E. V., Mazzotti, F. J. (2010) The rapid spread of invasive Eurasian Collared Doves Streptopelia decaocto in the continental USA follows human-altered habitats. Ibis, 152(3), pp. 622-632.

31. Galtier, N., Nabholz, B., Glémin, S., Hurst, G. D. D. (2009) Mitochondrial DNA as a marker of molecular diversity: a reappraisal, Molecular ecology, 18(22), pp. 4541-4550.

32. Garrido, O. H., Kirkconnell, A. (1990) La Tórtola Streptopelia decaocto (Aves: Columbidae) en Cuba, El Pitirre, 3(4), pp. 2.

33. Gibb, G. C., Penny, D. (2010) Two aspects along the continuum of pigeon evolution: a South-Pacific radiation and the relationship of pigeons within Neoaves, Molecular Phylogenetics and Evolution, 56(2), pp. 698-706.

34. Gibbons, D. W., Reid, J. B., Chapman, R. A. (1993) The new atlas of breeding birds in Britain and Ireland: 1988-1991. T \& A D Poyser Ltd., London, United Kingdom.

35. Glutz, V. B. U., Bauer, K. (1980) Handbuch der Vögel Mitteleuropas, Bd. 9. Columbiformes-Piciformes (pp. 64-140). Akademische Verlagsgesellschaft, Wiesbaden.

36. Goodwin, D. (1977) Pigeons and doves of the world. Cornell University Press, Ithaca, New York.

37. Gorski, W. (1993) Long-term dynamics of an urban population of collared dove (Streptopelia decaoto) from southern Baltic coast, The Ring, 15(1-2) pp. 86-96.

38. Grosso, A. R., Bastos-Silveira C., Coelho, M. M., Dias, D. (2006) Columba palumbus Cyt b-like Numt sequence: comparison with functional homologue and the use of universal primers, Folia Zoologica, 55(2), pp. 131.

39. Hajibabaei, M., Singer, G. A., Hebert, P. D., Hickey, D. A. (2007) DNA barcoding: how it complements taxonomy, molecular phylogenetics and population genetics, TRENDS in Genetics, 23(4), pp. 167-172.

40. Hayslette, S. E. (2006) Seed-size selection in Mourning Doves and Eurasian Collared-Doves, The Wilson Journal of Ornithology, 118(1), pp. 64-69.

41. Hebert, P. D., Cywinska, A., Ball, S. L. (2003) Biological identifications through DNA barcodes, Proceedings of the Royal Society of London B: Biological Sciences, 270(1512), pp. 313-321.

42. Hedrick, P. W, (2000) Genetics of populations. Jones \& Bartlett Learning, Sudbury, Massachusetts.

43. Hengeveld, R. (1993) What to do about the North American invasion by the Collared Dove?, Journal of Field Ornithology, pp. 477-489.

44. Hengeveld, R. (1988) Mechanisms of biological invasions, Journal of Biogeography, 15, pp. 819-828.

45. Hofstetter, F. B. (1954) Untersuchungen an einer Population der Türkentaube, Journal of Ornithology, 95(3), pp. 348-410.

46. Hooten, M. B., Wikle, C. K. (2008) A hierarchical Bayesian non-linear spatio-temporal model for the spread of invasive species with application to the Eurasian Collared-Dove, Environmental and Ecological Statistics, 15(1), pp. 59-70.

47. Hudson, R. (1965) The Spread of the Collared Dove in Britain and Ireland, British Birds, 58(4), pp. 105-139.

48. Hudson, R. (1972) Collared Doves in Britain and Ireland during 1965-1970, British Birds, 65, pp. 139-155.

49. Huey, R. B., Gilchrist, G. W., Hendry, A. P. (2005). Using invasive species to study evolution: case studies with Drosophila and Salmon. In: Sax, D. F., Stachowicz, J. J., Gaines, S. D. (Eds.). Species Invasions: Insights into Ecology, Evolution and Biogeography (pp. 139-164). Sinauer Associates Incorporated, Sunderland, Massachusetts.

50. Hughes, P. D. (2010) Little Ice Age glaciers in the Balkans: low altitude glaciation enabled by cooler temperatures and local topoclimatic controls, Earth surface processes and landforms, 35(2), pp. 229-241.

51. Johnsen, A., Rindal, E., Ericson, P. G. P., Zuccon, D., Kerr, K. C. R., Stoeckle, M. Y., Lifjeld, J. T. (2010) DNA barcoding of Scandinavian birds reveals divergent lineages in trans-Atlantic species, Journal of Ornithology, 151(3), pp. 565-578.

52. Johnson, K. P., Clayton, D. H. (2000a) Nuclear and mitochondrial genes contain similar phylogenetic signal for pigeons and doves (Aves: Columbiformes), Molecular phylogenetics and evolution, 14(1), pp. 141-151.

53. Johnson, K. P., Clayton, D. H. (2000b) A molecular phylogeny of the dove genus Zenaida: Mitochondrial and nuclear DNA sequences, The Condor, 102(4), pp. 864-870.

54. Johnson, K. P., Kort, S., Dinwoodey, K., Mateman, A. C., Cate, C. T., Lessels, C. M., Clayton, D. H. (2001) A molecular phylogeny of the Dove genera Streptotelia and Columba, The Auk, 118(4), pp. 874-887.

55. Jones, P. D., Bradley, R. S. (1992) Climatic variations over the last 500 years, Climate since AD, 1500, pp. 649-665.

56. Jonker, R. M., Kraus, R. H. S., Zhang, Q., et al. (2013) Genetic consequences of breaking migratory traditions in barnacle geese Branta leucopsis, Molecular ecology, 22(23), pp. 5835-5847.

57. Kan, X. Z., Yang, J. K., Li, X. F., Chen, L., Lei, Z. P., Wang, M., Qian, C. J., Gao, H., Yang, Z.Y. (2010) Phylogeny of major lineages of galliform birds (Aves: Galliformes) based on complete mitochondrial genomes, Genetics and Molecular Research, 9(3), pp. 1625-1633.

58. Kasparek, M. 1996. Dismigration und Brutarealexpansion der Türkentaube Streptopelia decaocto, Journal für Ornithologie, 137(1), pp. 1-33.

59. Kerr, K. C. R., Stoeckle, M. Y., Dove, C. J., Weigt, L. A., Francis, C. M., Hebert, P. D. N., (2007) Comprehensive DNA barcode coverage of North American birds, Molecular Ecology Resources, 7(4), pp. 535-543.

60. Kocher, T.D., Thomas, W. K., Meyer, A., Edwards, S. V., Pääbo, S., Villablanca, F. X., Wilson, A. C. (1989) Dynamics of mitochondrial DNA evolution in animals: amplification and sequencing with conserved primers, Proceedings of the National Academy of Sciences, 86(16), pp. 6196-6200. 
61. Kraus, R. H. S., Van Hooft, P., Megens, H-J., Tsvey, A., Fokin, S. Y., Ydenberg, R. C., Prins, H. H. T. (2013) Global lack of flyway structure in a cosmopolitan bird revealed by a genome wide survey of single nucleotide polymorphisms, Molecular ecology, 22(1), pp. 41-55.

62. Kraus, R. H. S., Wink, M. (2015) Avian Genomics - Fledging into the Wild!, Journal of Ornithology, 156(4), pp. 851-865.

63. Kvist, L., Arbabi, T., Päckert, M., Orell, M., Martens, J. (2007) Population differentiation in the marginal populations of the great tit (Paridae: Parus major), Biological Journal of the Linnean Society, 90(2), pp. 201-210.

64. Lee, C. E. (2002) Evolutionary genetics of invasive species, Trends in ecology \& evolution, 17(8), pp. 386-391.

65. Lopes, I. F., Miño, C. I., Del Lama, S. N. (2007) Genetic diversity and evidence of recent demographic expansion in waterbird populations from the Brazilian Pantanal, Brazilian Journal of Biology, 67(4), pp. 849-857.

66. Mallez, S., Castagnone, C., Espada, M., Vieira, P., Eisenback, J.D., Harrell, M., Guillemaud, T. (2015) Worldwide invasion routes of the pinewood nematode: What can we infer from population genetics analyses?, Biological invasions, 17(4), pp. 1199-1213.

67. Mayr, E. (1950) Speciation in birds, (pp. 91-131). In: Proc. X. Internat. Ornithol. Congr., Uppsala, Sweden.

68. Mayr, E. (1963) Animal species and evolution. Belknap Press of Harvard University Press, Cambridge, Massachusetts.

69. McCoy, K. D., Boulinier, T., Tirard, C., Michalakis, Y. (2003) Host-dependent genetic structure of parasite populations: differential dispersal of sea bird tick host races, Evolution, 57(2), pp. 288-296.

70. Moali, A., Moali-Grine, N., Fellous, A., Isenmann, P. (2003) Expansion spatiale de la tourterelle turque Streptopelia decaocto et préésence dans les parcs urbains du pigeon ramier Columba palumbus en Algérie, Alauda, 71(3), pp. 371-374.

71. Monceau, K., Cézilly, F., Moreau, J., Motreuil, S., Wattier, R. (2013) Colonisation and Diversification of the Zenaida Dove (Zenaida aurita) in the Antilles: Phylogeography, Contemporary Gene Flow and Morphological Divergence, PloS one, 8(12), pp. e82189.

72. Moritz, C. (1994) Applications of mitochondrial DNA analysis in conservation: a critical review, Molecular Ecology, 3(4), pp. 401-411.

73. Nowak, E. (1965). Die Türkentauben (Streptopelia decaocto). Ziemsen Verlag, Wittenberg Lutherstadt.

74. Nugroho, E. (2002) Rapid fluctuation of genetic variability in artificially propagated population of red sea bream, Indonesian Journal Agriculture Biotechnology. Indonesian Agency for Agriculture Research and Development, 7(1), pp. 17.

75. Ovenden, J. R., Macbeth, G. M., Pope, L., Thuesen, P., Street, R., Broderick, D. (2015) Translocation between freshwater catchments has facilitated the spread of tilapia in eastern Australia, Biological invasions, 17(2), pp. 637-650.

76. Prentis, P. J., Wilson, J. R. U., Dormontt, E. E., Richardson, D. M., Lowe, A. J., (2008) Adaptive evolution in invasive species, Trends in plant science, 13(6), pp. 288-294.

77. Pruett, C. L., Henke, S. E., Tanksley, S. M., Small, M. E., Hogan, K. M., Roberson, J. (2000) Mitochondrial DNA and morphological variation of White-winged Doves in Texas, The Condor, 102(4), pp. 871-880.

78. Ratnasingham, S., Hebert, P. D. N. (2007) BOLD: The Barcode of Life Data System: (http://www.barcodinglife.org), Molecular Ecology Resources, 7(3), pp. 355-364.

79. Robertson, H. A. (1990) Breeding of Collared Doves Streptopelia decaocto in rural Oxfordshire, England, Bird study, 37(2), pp. 73-83.

80. Rocha-Camerero, G., Hidalgo de Trucios, S. J. (2002) The spread of the Collared Dove Streptopelia decaocto in Europe: colonization patterns in the west of the Iberian Peninsula, Bird Study, 49(1), pp. 11-16.

81. Romagosa, C. M., McEneaney, T. (1999) Eurasian Collared dove in North America and the Caribbean, North American Birds, 53(4), pp. 348-353.

82. Romagosa, C. M., Labisky, R. F. (2000) Establishment and dispersal of the Eurasian Collared Dove in Florida, Journal of Field Ornithology, 71(1), pp. 159-166.

83. Sakai, A. K., Allendorf, F. W., Holt, J. S. et al. (2001) The population biology of invasive species, Annual review of ecology and systematics, 32(1), pp. 305-332.

84. Santiago-Alarcon, D., Tanksley, S. M., Parker, P. G. (2006) Morphological variation and genetic structure of Galapagos Dove (Zenaida galapagoensis) populations: issues in conservation for the Galapagos bird fauna, Wilson Journal of Ornithology, 118(2), pp. 194-207.

85. Sax, D. F., Stachowicz, J. J., Brown, J. H., Bruno, J. F., Dawson, M. N., Gaines, S. D., Grosberg, R. K., Hastings, A., Holt, R. D., Mayfield, M. M., O’Connor, M. I., Rice, W. R. (2007) Ecological and evolutionary insights from species invasions, Ecological and evolutionary insights from species invasions. Trends in ecology \& evolution, 22(9), pp. 465-471.

86. Scheidt, S. N., Hurlbert, A. H. (2014) Range Expansion and Population Dynamics of an Invasive Species: The Eurasian Collared-Dove (Streptopelia decaocto), PloS one, 9(10), pp. e111510.

87. Schindel, D. E., Stoeckle, M. Y., Milensky, C., Trizna, M., Schmidt, B., Gebhard, C., Graves, G. (2011) Project description: DNA barcodes of bird species in the National Museum of Natural History, Smithsonian Institution, USA, ZooKeys, (152), pp. 87.

88. Seki, S-I., Takano, H., Kawakami, K., Kotaka, N., Endo, A., Takehara, K. (2007) Distribution and genetic structure of the Japanese wood pigeon (Columba janthina) endemic to the islands of East Asia, Conservation genetics, 8(5), pp. 11091121.

89. Selander, R. K., Johnston, R. F., (1967) Evolution in the House Sparrow. I. Intrapopulation variation in North America, Condor. 69(3) pp. 217-258.

90. Shapiro, B., Sibthorpe, D., Rambaut, A., Austin, J., Wragg, G.M., Bininda-Emonds, O. R., Lee, P. L. Cooper, A. (2002) Flight of the dodo, Science, 295(5560), pp. 1683-1683.

91. Smith, P. W. (1987) The Eurasian Collared-dove arrives in the Americas, American Birds, 41(5), pp. 1370-1379.

92. Snow, D. W., Perrins, C. M., Gillmor, R. (1998). The birds of the western Palearctic, Non-passerines. Oxford University Press, Oxford, UK. 
93. Stevenson, H. M., Anderson, B. H. (1994). The birdlife of Florida. University Press of Florida, Gainesville, Florida.

94. Stockwell, C. A., Hendry, A. P., Kinnison, M. T. (2003) Contemporary evolution meets conservation biology, Trends in Ecology \& Evolution, 18(2), pp. 94-101.

95. Stresemann, E., Nowak E. (1958) Die Ausbreitung der Türkentaube in Asien und Europa, Journal of Ornithology, 99(3), pp. 243-296.

96. Syroteuk, M. (2008) First Occurrence of the Eurasian Collared-Dove (Streptopelia decaocto) in the west Kootenay Region of British Columbia, Wildlife Afield, 5, pp. 226-28.

97. Tabak, M. A., Poncet, S., Passfield, K., Carling, M. D., del Rio, C. M. (2015) The relationship between distance and genetic similarity among invasive rat populations in the Falkland Islands, Conservation genetics, 16(1), pp. 125-135.

98. Tanksley, S. M. (2000). Analysis of genetic differentiation in White-winged Doves. Ph.D. dissertation, A\&M University, College Station.

99. Temple, S. A. (1992) Exotic birds: a growing problem with no easy solution, The Auk, 109(2), pp. 395-397.

100. Thévenot, M., Vernon, R., Bergier, P. (2003). The birds of Morocco: an annotated checklist (No. 20). Tring, UK: British Ornithologists' Union.

101. Tsutsui, N. D., Suarez, A. V., Holway, D.A., Case, T. J. (2000) Reduced genetic variation and the success of an invasive species, Proceedings of the National Academy of Sciences, 97(11), pp. 5948-5953.

102. Wilcove, D. S., Rothstein, D., Dubow, J., Phillips, A., Losos, E. (1998) Quantifying threats to imperilled species in the United States, BioScience, 48(8), pp. 607-615.

103. Wink, M. (2006) Use of DNA markers to study bird migration, Journal of Ornithology, 147(2), pp. 234-244

Received: 10.04.2017.

Accepted: 23.12.2017.

Bagi Z., Kraus H. R., Kusza S.,(2017). A review of the invasive Eurasian Collared Dove and possible research methods in the future, Balkan Journal of Wildlife Research, 4(2), pp. 1-10. 